\title{
Implementing polyhydroxyalkanoates production to anaerobic digestion of organic fraction of municipal solid waste to diversify products and increase total energy recovery.
}

Gabriella Papa ${ }^{1}$, Tommy Pepe Sciarria ${ }^{1}$, Arianna Carrara ${ }^{1}$, Barbara Scaglia ${ }^{1}$, Giuliana D’Imporzano $^{1}$, Fabrizio Adani ${ }^{1 *}$

${ }^{1}$ Gruppo Ricicla - DiSAA - Università degli Studi di Milano, via Celoria 2, 20133 Milan, Italy

*Corresponding Author: e-mail: fabrizio.adani@unimi.it

\begin{abstract}
A simple biorefinery aimed at producing both biomethane $\left(\mathrm{CH}_{4}\right)$ and polyhydroxyalkanoates (PHAs), was proposed to valorize the organic fraction of municipal solid waste (OFMSW). Anaerobic digestion (AD) was tested at different organic loading rates (OLR-I-II-III) (i.e. 3, 4 and $6 \mathrm{~g} \mathrm{~L}^{-1} \mathrm{~d}^{-1}$, respectively), producing biomethane and volatile fatty acids (VFAs)-rich digestate, the VFAs were then used to produce PHAs. Specific biogas and $\mathrm{CH}_{4}$ production remained similar when adopting different OLRs (biogas of 522-600 $\mathrm{NL} \mathrm{kg}^{-1} \mathrm{VS}$ and $\mathrm{CH}_{4}$ of $64-67 \% \mathrm{v} / \mathrm{v}$ ). VFAs concentrated with OLR increases and their patterns were modified. PHA production was in the range of $117-199 \mathrm{~g} \mathrm{~kg}^{-1}$ OFMSW $\mathrm{TS}$ with the lowest production being associated to different polymer composition.

The net energy recovery of this simple biorefinery accounted for 64\% of OFMSW energy content, and the PHAs produced represented over $30 \%$ of the total energy.
\end{abstract}




\section{Keywords}

Anaerobic Digestion; Organic Loading Rate; Organic Fraction of Municipal Solid Waste (OFMSW); Polyhydroxyalkanoates (PHAs); Volatile Fatty Acids (VFAs). 


\section{Introduction}

The transformation of low value waste materials such as municipal solid waste (MSW) into renewable chemicals, energy and biofuels, supports the development of a circular economy model by closing the waste loop and meeting the EU Strategy (COM (2015) 80 final) goals (Moretto et al., 2020; Scarlat et al., 2019).

Worldwide, the generation of MSW stands at about 1.3 billion $\mathrm{Mg}$ annually and is expected to rise to about 2.3 billion Mg by 2025 (Hoornweg and Bhada-Tata, 2012), while in the EU it is expected to reach 271 million $\mathrm{Mg}$ in 2020, with organic contents being more than $40 \%$ by weight, depending on countries, climates, socio-economic and geographical conditions (Colombo et al., 2017). Among major MSW producers, Italy generates an estimated 30 million $\mathrm{Mg}$ per year of waste, of which about 8 million $\mathrm{Mg}$ ending up in landfills, although there are relatively high recycling and composting rates of over 5 and 7.6 million Mg, respectively (Scarlat et al., 2019).

During the last 20 years, progress has been made to develop an integrated MSW management approach and to treat separately the collected organic fraction of municipal solid waste (OFMSW) (Girotto et al., 2015a). Among the several biomass conversion technologies available for energy and material recovery from OFMSW, anaerobic digestion $(\mathrm{AD})$ is considered one of the most promising and sustainable methods (Di Maria et al., 2019). Recently, the OFMSW has been recognized as a viable resource for $\mathrm{AD}$, and its use as a non-food source for renewable energy production also offers important advantages in terms of waste reduction and recycling optimization, which minimizes the amount of materials destined for landfills (Eriksson et al., 2015). 
Biomethanation, a sustainable approach to produce renewable gas and other products, could represent a realistic alternative to fossil-oil based energy (Molino et al., 2013). Across the EU there are already over 17,000 biogas digesters and Italy, one of the leading countries in this respect with its $1,500 \mathrm{AD}$ operating units, could have a great potential for the utilization of a biorefinery chain in the urban scenario (Moretto et al., 2020). AD is a well-known and established strategy for the treatment of organic waste. As well as biogas, it produces a renewable fertilizer i.e., digestate (Arthurson, 2009).

During a typical AD process, the consortia of different bacteria generate, as intermediates and co-products in the methane formation pathway, the short chain volatile fatty acids (VFAs) which include, for example acetic, butyric, propionic and valeric acids (Khan et al., 2016). These functional molecules act as the direct precursors and building blocks for further conversion into bio-based chemicals such as polyhydroxyalkanoates (PHAs) (Cavinato et al., 2017), a class of biodegradable polyesters of microbial origin that are attracting attention as replacements for petroleum-based plastics (Reddy et al., 2003). PHA are sold at prices much higher than those for biogas; therefore their production through the $\mathrm{AD}$ route could bolster the overall economics of an AD-biorefinery using VFAs from AD of OFMSW as an inexpensive C feedstock for producing PHAs (Valentino et al., 2018).

Despite the vast amount of research focused on bio-waste conversion into VFAs and biogas as well on valorization of VFA to PHA from mixed microbial cultures (MMCs), there is still much to understand in terms of performance and process integration. Moreover, varying the $\mathrm{AD}$ process parameters and operational conditions has marked effects on the quality of the VFAs-rich stream generated. It is well known that reducing 
HRT (increasing OLR) leads to VFA accumulation and modification of the VFA pattern (Sarker et al., 2019). Variations in the proportion of even-chain (e.g., acetic acid) to oddchain (e.g., propionic acid) carbon finally affects the composition of PHA co-polymers and consequently their physical and mechanical attributes (Valentino et al., 2014; Albuquerque et al., 2011; Bengtsson et al., 2010). AD manipulation to obtain VFA profiles' modification has been studied recently by adopting different hydraulic retention times (HRTs) and organic loading rates (OLRs) or by modification of the microbial community (e.g. Jankowska et al., 2015; Pittmann and Steinmetz, 2013). On the other hand, VFA (and ammonia) accumulation could inhibit the AD process, reducing total biogas (bio-methane production). Therefore, managing the $\mathrm{AD}$ process can affect both $\mathrm{CH}_{4}$ and PHA via the VFA pathway (Colombo et al., 2016; Colombo et al., 2017) and lead to changes in the total energy balance.

This paper aims, starting from a full scale AD process configured to produce biogas and digestate for agricultural use, to investigate the possibilities for producing and recovering VFAs to be then used in producing PHA, maximizing both biogas and VFA production by a simple biorefinery-AD approach. Mass balance, and the energy balance of this simple biorefinery are also measured in this study.

\section{Materials and methods}

\subsection{Feeding mixture to anaerobic digesters}

The OFMSW was collected from a full-scale AD plant located in northern Italy. The plant (1 MW of electrical power), situated in a farm, consisted of a homogenizing tank in which the feeding mixture, consisting of a puree of OFMSW from source- 
separated collections mixed with digestate at a ratio of 10: $1(\mathrm{w} / \mathrm{w})$, was fed to four continuous stirred tank reactors (CSTRs). The hydraulic retention time (HRT) of the digesters was $40 \mathrm{~d}$, and the plant worked in wet conditions, i.e., with total solids (TS) below $150 \mathrm{~g} \mathrm{~kg} \mathrm{TS}^{-1}$. The OFMSW mix for experimentation was collected directly from the feeding pipeline and then stored at $4{ }^{\circ} \mathrm{C}$ before the experiments were set up.

\subsection{Bioprocesses set up}

\subsubsection{Biomethane and organic acids production via anaerobic digestion}

The AD processes were carried out in the laboratory in a continuously stirred tank reactor (CSTR) with $2 \mathrm{~L}$ of total volume and $1.5 \mathrm{~L}$ of active volume, under continuous mixing (90 $\mathrm{rpm})$. The reactors were placed in a thermostatically controlled water bath to ensure a constant thermophilic temperature $\left(55 \pm 1^{\circ} \mathrm{C}\right)$.

The AD experiments started by using the full scale plant HRT, i.e. $40 \mathrm{~d}$ (OLR of $3 \mathrm{~kg}$ VS $\mathrm{m}^{-3}$ reactor $\left.\mathrm{d}^{-1}\right)$, which was then lowered to $30 \mathrm{~d}\left(4 \mathrm{~kg} \mathrm{VS} \mathrm{m}^{-3}\right.$ reactor $\left.\mathrm{d}^{-1}\right)$ in the second treatment, and finally, reduced to $20 \mathrm{~d}\left(6 \mathrm{~kg} \mathrm{VS} \mathrm{m}^{-3}\right.$ reactor $\left.\mathrm{d}^{-1}\right)$ in the third treatment (Table 1). The first experiment was performed by filling the reactor with an inoculum obtained from the full-scale plant to seed the digesters and then starting the reactor was fed daily with the OFMSW mix at the rate of $3 \mathrm{~kg} \mathrm{VS} \mathrm{m}^{-3}$ reactor $\mathrm{d}^{-1}$, i.e. HRT of 40 , for 50 days, allowing complete washout and getting constancy in biogas production. The washout procedure, getting constant biogas production, was adopted every time the HRT was changed.

Each day the same volume of digestate was withdrawn from the digesters and replaced with an equal volume of feed. After the daily feeding, the reactors were sealed and the 
headspace was fluxed with $\mathrm{N}_{2}$. Daily biogas production was collected in a $4 \mathrm{dm}^{3}$ gas collecting bag (Gas Sampling Bags SupelTM Inert Multi-Layer Foil) coupled to each reactor and the biogas yield was determined with a Ritter Drum (Gas Meter TG 0.5/5, Germany) by connecting the detached gasbag to the gas meter. The generated biogas volume was collected and analyzed using a gas chromatograph $(\mu \mathrm{GC} ; 3000 \mathrm{~A}-\mu \mathrm{GC}$, AGILENT-SRA Instruments) as previously described (Colombo et al., 2007). All experiments were performed in duplicate trials and the data were reported as the mean \pm standard deviation.

The effluent samples including volatile fatty acids (VFAs) coming from the AD retained daily, were mixed and stored at $-20^{\circ} \mathrm{C}$ for further analysis and PHA production experiments.

\subsubsection{PHA Culture Selection/Enrichment and PHA Accumulation stage}

The digestates from $\mathrm{AD}$ were employed as feed-substrates in the selection and PHA accumulation processes and they were characterized in terms of $\mathrm{pH}$, TSS, VSS, soluble COD, VFA content (acetate, butyrate, lactate, propionate and valerate), TKN, N-NH${ }_{4}^{+}$ and phosphorus (P) content as previously described (Colombo et al., 2017). Prior to their use as the VFA-rich substrate for PHA production, the digestates were centrifuged at 4,000 rpm for $15 \mathrm{~min}$ to reduce the solid contents. For the enrichment of PHA accumulating bacteria at the selection stage, the ammonia was stripped out of the digestate in order to keep the $\mathrm{C}: \mathrm{N}$ ratio between $8-10$, then dilution was made to a final COD of about 40 mmole $\mathrm{L}^{-1} \mathrm{COD}$. For the next step of PHA accumulation, the ammonia in the substrates was further stripped out, before dilution to $200 \mathrm{mmole}^{-1} \mathrm{COD}$, as $\mathrm{N}$ starvation was required for a greater C conversion to PHA (Colombo et al., 2019). 
The PHA-producing bacteria selection (mixed microbial culture) (MMC) was performed in a first stage by using an inoculum constituted by activated sludge (Colombo et al., 2017) (8 $\mathrm{g}$ of total suspended solids $\left.\mathrm{L}^{-1}\right)$ collected from the secondary sedimentation tank of a wastewater treatment plant. The selection process was performed in a $2 \mathrm{~L}$ Erlenmeyer flask with a working volume of $0.75 \mathrm{~L}$, by carrying out at least 3 sludge retention time cycles (SRT) of 5 days each, applying an aerobic dynamic feeding (ADF) strategy (Colombo et al., 2017). Several (about 30) sequential batch bioreactor (SBR) cycles/runs were performed. Briefly, the hydraulic retention time (HRT) of 1 day consisted of two cycles of $12 \mathrm{~h}$, each including four phases (i.e. feeding-filling, aeration stirring, settling and withdrawal of the effluent). Feeding flow (pumping $0.36 \mathrm{~L} \mathrm{~min}^{-1}$ ), aeration supplied from an air pump through ceramic diffusers (flow rate $6 \mathrm{~L} \mathrm{~min}^{-1}$ ) and stirring $(110 \mathrm{rpm})$ were automatically controlled. The temperature was maintained at 25 ${ }^{\circ} \mathrm{C}$ and $\mathrm{pH}$ at 8.8 through additions of $1 \mathrm{~mole}^{-1}$ of $\mathrm{HCl}$ with an automatic controlling system.

Prior to each accumulation, the biomass was subjected to a selection/acclimation phase. This phase involved a sequence of 30-40 feast and famine cycles (i.e. SRT). The feast in each cycle was obtained by stimulating the biomass to respiration with an input of substrate to a maximum CODs concentration of 1,500-1,900 $\mathrm{mg} \mathrm{COD} \mathrm{L}^{-1}$. The changes of dissolved oxygen (DO) concentration were monitored continuously by optical probe (FDO 925, WTW, Germany) and used to identify the length of time of the feast period and the feast to famine ratio $(\mathrm{F} / \mathrm{F})$ observed to be equal or less than 0.33 (Colombo et al., 2017; Valentino et al., 2014; Duque et al., 2014). The performance of the selected culture was assessed during the selection trial by monitoring through each 
SRT the total suspended solids (TSS), volatile suspended solids (VSS), soluble COD, VFA content, ${\mathrm{N}-\mathrm{NH}_{4}}^{+}$and PHA content.

In the following fed-batch PHA accumulation tests, the selected/enriched consortium was evaluated for PHA-storing efficiency during an experimental trial that employed a $0.2 \mathrm{~L}$ working volume flask with continuous aeration and stirring. In particular, a pulsed feeding was applied to PHA accumulation trials and controlled by the decrease in biomass respiration as measured by DO trends. The addition of the carbon feedstock aliquot was chosen based on COD concentration which was to be the same as that inside the selection reactor (i.e., around $20 \mathrm{mmol} \mathrm{L}^{-1}$ ), targeting COD concentrations of about $1,500 \mathrm{mg}^{-C O D ~ \mathrm{~L}^{-1}}$. The substrate was fed into the digester till no DO variation was observed. Throughout each cycle, samples were taken at selected times (i.e., at the beginning and at the end of the feast phase) for analyses that included: VSS, TSS, PHA content and composition, soluble COD, volatile fatty acids (VFAs). All the assays were carried out in triplicate.

\subsection{Stream characterization}

\subsubsection{Digestate characterization}

Samples from the digesters were daily collected for measurements of $\mathrm{pH}$, total COD (CODt), soluble COD (CODs), TKN, $\mathrm{N}_{-} \mathrm{NH}_{4}{ }^{+}$, organic acids content and alkalinity according to Standard Methods (APHA, 1998) and using photometric test kits (NANOCOLOR $®)$ as well the total solids (TS) and volatile solids (VS) as described previously (Colombo et al., 2019). 
The combination of representative samples from daily sampling was used as the substrates for PHA production during the selection and accumulation stages after being fully characterized in terms of VFA, COD and $\mathrm{N}_{-} \mathrm{NH}_{4}^{+}$.

Inductively coupled plasma-optical emission spectrometry (ICP-OES) (AX liberty, Varian. Fort Collins, USA) was used to measure the concentration of trace elements in the digestate by digestion the samples in concentrated $\mathrm{HNO}_{3}$ and $\mathrm{H}_{2} \mathrm{O}_{2}$ according to standard procedures (APHA, 1998) (EPA, 1996).

VFAs speciation and quantification were obtained by a Shimazu HPLC, (Shimadzu Corporation, Tokyo, Japan), with a Hi-Plex H Agilent column (300 x 7 mm, PL11706830) (Agilent Technologies, Santa Clara, CA, USA). The refractive index detector (RID) was held at $35^{\circ} \mathrm{C}$. The HPLC was equipped with an RID. The samples were run injecting $20 \mu \mathrm{L}$, using an isocratic $4 \mathrm{mmol} \mathrm{L}^{-1}$ sulfuric acid eluent at $0.4 \mathrm{~mL} \mathrm{~min}^{-1}$ and 50 ${ }^{\circ} \mathrm{C}$ for 40 minutes. Samples for VFA analysis were centrifuged at 13,000 rpm for $5 \mathrm{~min}$ to pellet solid and filtered through a $0.2-\mu \mathrm{m}$ filter (VWR) by centrifugation $(13,000 \mathrm{rpm}$ for $3 \mathrm{~min}$ ). Quantification was made by reference to standard curves of seven dilutions of succinic, acetic, propionic, butyric and valeric acids. The concentrations were calculated using the Labsolution 5.90 (Shimadzu Corporation, Tokyo, Japan) software package integrating the area under each compound detection peak.

\subsubsection{PHA characterization}

PHA recovery was achieved following the chloroform extraction method (Villegas Calvo et al., 2018). Determination of PHA was carried out using a gas chromatograph (GC) equipped with mass spectrometry (MS) (7980, Agilent Technologies, USA). The compounds were separated using a ZB-Wax column $(30 \mathrm{~m} \AA \sim 0.25 \mathrm{~mm} \times 0.25 \mu \mathrm{m}$, 
Zebron, Phenomenex, USA) capillary column. One $\mu$ l of the sample was injected into the $\mathrm{GC}$ at an inlet temperature of $280^{\circ} \mathrm{C}$ and was operated in a split mode (split flow of 30 $\mathrm{mL} / \mathrm{min}$, split ratio $=30$ ). Helium was used as the carrier gas with a constant flow rate of $1 \mathrm{~mL} \min ^{-1}$. The temperature of the $\mathrm{GC}$ was held at $40{ }^{\circ} \mathrm{C}$ for $5 \mathrm{~min}$ and then it was increased at a rate of $20{ }^{\circ} \mathrm{C} \min ^{-1}, 38^{\circ} \mathrm{C} \mathrm{min}^{-1}$ and $20^{\circ} \mathrm{C} \mathrm{min}^{-1}$, up to $100{ }^{\circ} \mathrm{C}, 175^{\circ} \mathrm{C}$ and $220^{\circ} \mathrm{C}$, respectively. Quantification was made by reference standard commercial P (HBHV) (88\%/12\%) (Sigma Aldrich, Germany) of six-point calibration curve, 0.0176-0.7 mg $\mathrm{mL}^{-1}$ for PHB and $0.0024-0.096 \mathrm{mg} \mathrm{mL}^{-1}$ for PHV, corrected using heptadecane $\left(0.1 \mathrm{~g} \mathrm{~L}^{-}\right.$

${ }^{1}$ ) as internal standard. The instrument control and data processing were carried out using the Agilent ChemStation software.

\subsection{Calculation of kinetic and stoichiometric parameters during PHA production}

In the selection and accumulation phase the PHA cell content was referred to VS, on a mass basis ( $\mathrm{g} \mathrm{kg}^{-1} \mathrm{VS}$ ), considering VS to be constituted by both PHA and active biomass (Duque et al., 2014). PHA was transformed into COD considering the stoichiometry of $1.67 \mathrm{mg} \mathrm{COD} \mathrm{mg}^{-1} \mathrm{HB}$ and $1.92 \mathrm{mg} \mathrm{COD} \mathrm{mg}^{-1} \mathrm{HV}$ monomer (Valentino et al., 2014). $\mathrm{HB}$ precursors were assumed to be acetate while the propionate precursor was $\mathrm{HV}$ (Duque et al., 2014). Active biomass $\left(\mathrm{X}_{\mathrm{a}}\right)$ was calculated on a COD basis $\left(\mathrm{g} \mathrm{L}^{-1}\right)$ relying on this conversion: $1 \mathrm{~g}$ of $\mathrm{X}_{\mathrm{a}}$ contains $1.42 \mathrm{~g}$ of COD (Valentino et al., 2014). For the sequencing batch reactors, PHA produced in each cycle $(\triangle \mathrm{PHA})(\%, \mathrm{w} / \mathrm{w})$ was calculated taking into account the PHA content at the end of the feast phase and the PHA content immediately upon substrate addition (Oliveira et al., 2017). 
The parameters considered were calculated in the following way: i. the specific COD consumption rate (-qCOD, $\left.\mathrm{mg} \mathrm{COD} \mathrm{g}^{-1} \mathrm{COD}_{\mathrm{X}} \mathrm{h}^{-1}\right)$ as the COD consumed during the feast phase and the time needed to deplete it per unit of active biomass; ii. the specific PHA storage rate (qPHA, mg CODPHA $\mathrm{g}^{-1} \mathrm{COD}_{\mathrm{X}} \mathrm{h}^{-1}$ ) as the amount of PHA stored during the feast phase vs. the time needed to deplete the COD per unit of active biomass; iii. the specific growth rate ( $\mathrm{q}_{\mathrm{X}}$ feast, $\left.\mathrm{mg} \mathrm{COD}_{\mathrm{X}} \mathrm{g}^{-1} \mathrm{COD}_{\mathrm{X}} \mathrm{h}^{-1}\right)$ as the amount of new active biomass produced during the feast phase vs. the time needed to deplete the COD per unit of active biomass (Valentino et al., 2014). In SBR only - qCOD e qPHA were calculated for each dose of given feeding solution.

PHA yield for the SBR was determined considering the PHA stored, expressed as COD, vs. the amount of COD consumed (Y $\mathrm{YHA}_{\mathrm{PH} / \mathrm{COD} \text { cons., }} \mathrm{mg}$ CODPHA $\mathrm{mg}^{-1} \mathrm{COD}_{\text {cons }}$ ) and vs. the amount of organic acids (OA) depleted (Y addiction PHA yield was also reported on COD fed ( $\mathrm{Y}_{\mathrm{PHA} / \mathrm{CODin}}, \mathrm{mg} \mathrm{COD}_{\mathrm{PHA}} \mathrm{mg}^{-1} \mathrm{COD}_{\mathrm{IN}}$ o g PHA g $\left.{ }^{-1} \mathrm{COD}_{\mathrm{IN}}\right)$ organic acids (OA) fed expressed as COD (Y $\mathrm{mg}^{-1} \mathrm{COD}_{\mathrm{AO}}$ IN o g PHA g $\left.{ }^{-1} \mathrm{AO}_{\mathrm{IN}}\right)$ (Valentino et al., 2014).

PHA productivity (g PHA L $\mathrm{L}^{-1} \mathrm{~d}^{-1}$ ) was expressed as the ratio between the obtained PHA at the end of the test (g PHA L ${ }^{-1}$ ) and the whole test time (h) (Valentino et al., 2014)) and it was also referred OFMSW fresh and dry matter (g PHA kg-1 OFMSW) (Colombo et al., 2017).

\subsection{Statistical analysis}

Average and standard deviation values were calculated according to standard procedures and the data were analyzed for statistical significance by a one-way analysis of variance 
(ANOVA) and Tukey test $(\mathrm{P}<0.05)$ by using SPSS software 200 (SPSS Statistics v21.0, IBM, Armonk, NY, USA).

\section{Results and discussion}

\subsection{OFMSW composition and characteristics}

The chemical features of the OFMSW feedstock used for AD are presented in Table 2. An average TS content of $158 \pm 25 \mathrm{~g} \mathrm{~kg}^{-1} \mathrm{ww}$ and an average VS content of $123 \pm 20 \mathrm{~g} \mathrm{~kg}^{-1}$ ww (i.e., $770 \pm 2 \mathrm{~g} \mathrm{~kg}^{-1} \mathrm{TS}$ ) were detected, this latter indicating a high content of biodegradable organic matter potentially capable of being transformed into biogas. The OFMSW contained $93.6 \mathrm{~g} \mathrm{~L}^{-1}$ and $60.5 \mathrm{~g} \mathrm{~L}^{-1}$ of total and soluble COD, respectively, which corresponded to $609 \pm 15 \mathrm{~g} \mathrm{COD} \mathrm{kg}^{-1} \mathrm{TS}$ and $383 \pm 10 \mathrm{~g} \mathrm{COD} \mathrm{kg}^{-1} \mathrm{TS}$, respectively. The nutrient level was that typical of OFMSW content with nitrogen of $27 \pm 1 \mathrm{~g} \mathrm{~N} \mathrm{~kg}^{-1} \mathrm{TS}$ on average and a CODs/N of 100/14. The OFMSW showed a VFA concentration of $23,534 \pm 1,778 \mathrm{mg} \mathrm{L}^{-1}$, i.e. $149 \pm 11 \mathrm{~g} \mathrm{~kg}^{-1} \mathrm{TS}$, an alkalinity of 19,263 $\pm 640 \mathrm{mg} \mathrm{CaCO}_{3} \mathrm{~L}^{-1}$ and sub-acid pH, i.e. $6 \pm 0$.

In general, the characterization of OFMSW and values of TS\% and VS\% were in line with those obtained in previous work on OFMSW in anaerobic digestion (Canul Bacab et al., 2020; Dang et al., 2016).

\subsection{Anaerobic Digestion: biomethane and VFA production}

\subsubsection{Biogas-Biomethane production}

To maximize both biogas and VFA production starting from the full scale AD plant configuration (OLR of $3 g_{v s} L_{\text {react }}{ }^{-1} d^{-1}$ and HRT of $40 \mathrm{~d}$ ), AD experiments were carried 
out at lab scale adopting three different OLRs $\left(3,4\right.$ and $6 \mathrm{~g}_{\mathrm{vs}} \mathrm{L}_{\text {react }}{ }^{-1} \mathrm{~d}^{-1}$, i.e., HRT of 4030-20 d, respectively). At OLR-I ( $\left.3 \mathrm{~g}_{\mathrm{vs}} \mathrm{L}_{\text {react }}{ }^{-1} \mathrm{~d}^{-1}\right)(\mathrm{HRT}$ of $40 \mathrm{~d})$, the average daily biogas production was of $1.5 \pm 0.1 \mathrm{NL} \mathrm{L}_{\text {react }}^{-1} \mathrm{~d}^{-1}$ and the specific biogas produced during trial was, on average, of $522 \pm 27 \mathrm{NL} \mathrm{kg}^{-1} \mathrm{VS}$. Increasing the OLR rates to $4 \mathrm{~g}_{\mathrm{vs}} \mathrm{L}_{\text {react }}{ }^{-1} \mathrm{~d}^{-1}$ (OLR-II) (HRT of $30 \mathrm{~d}$ ) resulted into a slightly higher but not significantly different specific biogas yield (i.e., $600 \pm 51 \mathrm{NL} \mathrm{kg}^{-1} \mathrm{VS}$ ), and similarly it was of $567 \pm 25 \mathrm{~N} \mathrm{~L} \mathrm{~kg}^{-1}$ VS when OLR further raised to $6 \mathrm{~g}_{\mathrm{vs}} \mathrm{L}^{-1} \mathrm{~d}^{-1}$ (HRT of $20 \mathrm{~d}$ )(Table 3). Most of reports on impact of OLR on AD, showed results that associated its increase to a proportional decrease in the specific biogas yield generally due to inhibition because of both ammonia and VFA concentration (Rajput and Sheikh, 2019). Nevertheless, this study revealed similar specific biogas yields ( $\left.\mathrm{NL} \mathrm{kg}^{-1} \mathrm{VS}\right)$ at different OLRs tested, indicating that although reducing HRT (increasing OLR) led to strong VFA and ammonia concentration (Table 1) that were both above the value reported to be toxic for AD (Sarker et al., 2019; Chen et al., 2008), the specific biogas production was not reduced, i.e., no inhibition occurred. This fact was truer above all for OLR of $6 \mathrm{~g} \mathrm{VS} \mathrm{Lreact}^{-1} \mathrm{~d}^{-1}$ (i.e. HRT of 20d). Increasing OLR without AD inhibition, led to much more biomethane production per reactor volume ( $\mathrm{g} \mathrm{VS} \mathrm{L}_{\text {react }}^{-1} \mathrm{~d}^{-1}$ ) (Table 3$)$, in fact about twice as much was produced from the shorter HRT when comparing OLR-I to OLR-III. These results confirmed the potential of reducing the operation time (i.e. HRT), allowing the maintenance of good biogas yields and potentially improving the economic efficiency and viability of the AD process. Furthermore, the results showed that the average concentration of methane content $(\% \mathrm{v} / \mathrm{v})$ in the biogas did not change significantly throughout the different experimental periods, with values in the range of $64 \%$ to $67 \%(\mathrm{v} / \mathrm{v})$ and similar to those 
previously reported (Valentino et al., 2019). Overall, the cumulative biogas and biomethane yield obtained in this study were in line with results reported in literature for similar substrates and OLRs (Agyeman and Tao, 2014). It has been recognized that methane production from OFMSW typically ranges between 300 and $600 \mathrm{NL} \mathrm{kg}^{-1} \mathrm{VS}$ for VS/TS ratio between 0.75 and 0.95 (Campuzano and González-Martínez, 2016). Again, Valentino et al., (2019) found biogas yields of 400-450 $\mathrm{L} \mathrm{kg}^{-1} \mathrm{VS}$ in a study conducted on OFMSW and waste activated sludge mixture under mesophilic fermentation, with all the literature data listed above being in line with those of this work.

\subsection{2. $C O D$ removal and $A D$ parameters.}

Taking into consideration tests for the treatment OLR-I, the results showed an average of CODt of $28 \pm 5 \mathrm{~g} \mathrm{~L}^{-1}$, while at OLR-II and OLR-III the CODts observed were of $49 \pm 8$ and $55 \pm 10 \mathrm{~g} \mathrm{~L}^{-1}$, respectively, which corresponded to COD removal rates of $81 \pm 15 \%$, $66 \pm 11 \%$ and $62 \pm 11 \%$, respectively for the three OLRs studied (calculated from Table 2). These results reflected well the VS destruction found in the digestates, calculated to be of $83.7 \%, 70 \%$ and $62 \%$ of the VS added, respectively, for OLR-I-II and III.

The three digestates showed a similar constant $\mathrm{pH}(\mathrm{pH}$ of 8 ) and organic acids vs. alkaline buffer ratio capacity in the range $0.2-0.5$, all indicating a stable AD process. The ammonia digestate concentration varied among the different OLRs tested, increasing from $2.2 \pm 0.3$ (OLR-I) to $6.6 \pm 0.1{\mathrm{~g} \mathrm{~N}-\mathrm{NH}_{4}}^{+} \mathrm{L}^{-1}$ (OLR-III), this latter above the value reported to inhibit methanogenic bacteria. Interestingly, the absence of trace element supplementation did not yield any negative effect on the biomethane production with OLR modification, indicating that they were able supporting $\mathrm{AD}$, such as confirmed by trace elements content measured in the digestate and showed in the Supplementary Data. 


\subsubsection{VFA yields and characterization}

The combination of representative samples of digestates from daily sampling showed final VFAs titers of 3,158 $\pm 26,5,261 \pm 199$ and $6,871 \pm 71 \mathrm{mg} \mathrm{L}^{-1}$, respectively for OLR III-III, indicating that VFAs accumulated with OLR increasing (Table 2).

VFAs presence during AD processes at the different OLRs reflected the VFAs already present in the OFMSW substrate (VFA of 23,534 $\pm 1,778 \mathrm{~g} \mathrm{~L}^{-1}$ ) (Table 2) that were preserved or transformed into biogas depending on the OLRs and HRTs adopted, i.e. longer HRT (lower OLR) led to VFA degradation and shorter HRT (higher OLR) led to VFA preservation. This fact was confirmed by the VFA profiles (Table 2) (Figure 1) that revealed that VFAs metabolized during the $\mathrm{AD}$ were mainly butyric and acetic acids that diminished greatly with respect to their contents in the starting organic matrix. On the other hand, propionic acid diminished greatly during AD for the highest HRT (40 d), but it tended to accumulate with HRT reduction (OLR increase), reflecting its high content in the starting organic matrix. For HRT of $30 \mathrm{~d}$ and $20 \mathrm{~d}$ (OLR-II and OLR-III), propionic acids represented $73 \%$ and $85 \%$ of total final VFA content, respectively (Table 2).

The VFAs concentration never achieved values which could cause instability of the AD process by lowering methane production, i.e., 11 to $16 \mathrm{~g} \mathrm{TS} \mathrm{L}^{-1} \mathrm{~d}$ (Jiang et al., 2013) or even $\mathrm{AD}$ process inhibition, i.e. $16.5-18.0 \mathrm{~g} \mathrm{~L}^{-1}$ (Jiang et al., 2018).

The presence of high levels of propionic acid and in general VFAs concentration higher than $5 \mathrm{~g} \mathrm{~L}^{-1}$ have been reported to result in significant inhibition activity for the methanogens and for the overall biogas performance (Jiang et al., 2018; Chen et al., 2008). Others authors found that even a concentration of $0.9 \mathrm{~g} \mathrm{~L}^{-1}$ propionic acid could 
inhibit the methanogens (Wang et al., 2009). However, the fermentation inhibitors information is not available in all sources, precluding a proper comparison among experiments, beside which, there is no consensus of opinions, that vary regarding which VFA is the best indicator for impending reactor failure (Franke-Whittle et al., 2014). The daily VFAs accumulation ( $\mathrm{mg}$ VFA L $\left.{ }^{-1} \mathrm{~d}^{-1}\right)$ obtained in this study, i.e. $344 \pm 1.8 \mathrm{mg}$ VFAs $\mathrm{L}^{-1} \mathrm{~d}^{-1}$ for OLR-III, whereas in the OLR-I and OLR-II cases the daily VFAs levels in the digestate were lower i.e., $79 \pm 0.6$ and $175 \pm 5 \mathrm{mg} \mathrm{VFAs} \mathrm{L}^{-1} \mathrm{~d}^{-1}$, respectively (Table 3) was much lower than that found previously by Lim et al. (2008), who working on food waste reported 1,630-3,750 $\mathrm{mg} \mathrm{VFA} \mathrm{L}^{-1} \mathrm{~d}^{-1}$, although shorter HRT and higher OLR (i.e., 8,000 $\mathrm{d}$ and 5,000-13,000 $\mathrm{mg} \mathrm{L}^{-1} \mathrm{~d}^{-1}$ ) were employed. Again, the VFAs amount (i.e., g of VFA observed per kg of substrate VS) that was different among the three scenarios, i.e., $28 \pm 0 \mathrm{~g} \mathrm{VFA} \mathrm{kg}^{-1} \mathrm{VS}, 43 \pm 1 \mathrm{~g}^{\mathrm{VFA} \mathrm{kg}}{ }^{-1} \mathrm{VS}$ and $57 \pm 0 \mathrm{~g} \mathrm{VFA} \mathrm{kg}^{-1} \mathrm{VS}$ for OLR-I, OLR-II and OLR-III, respectively were much lower than those reported for similar substrates by Lim et al., (2008), i.e. 0.29-0.30 g VFA g SV ${ }^{-1}$ and Slezak et al., (2017), i.e. $0.20 \mathrm{~g}$ VFA $\mathrm{g} \mathrm{SV}^{-1}$. This resulting digestate stream and these distributions among acetic and propionic were used as feedstocks for PHA production (Table 4).

The high presence of VFA in starting material (VFA of 23,534 $\pm 1,778 \mathrm{~g} \mathrm{~L}^{-1}$ ) (Table 2) due to acidogenic fermentation occurred during transportation of OFMSW to the full scale plant and the successive its preservation in storage tank, suggested that further work for optimization of PHA and biogas production should be realized taking into consideration VFAs separation before the AD process. Then comparative studies must be carried out to understand and establish for each approach the effect on the overall performance in terms of bio-methane, PHA and energy balance. 


\subsection{PHA production: biomass selection and PHA accumulation using the VFA-rich digestate feedstock under Aerobic Dynamic Feeding in SBR.}

The combination of daily samplings of each digestate from AD at OLR-I-II-III, after the solids were removed from the liquid fraction, was employed as substrates to select PHA storing bacteria (Colombo et al., 2017). The MMC enrichment phase remained relatively stable during the entire selection process, apart from a few complications due to the solidlike material formed attached to the glass wall of reactor, which was removed by manual means, as well as some foaming, likely due to additional disintegration of organic material. During the selection, the dissolved oxygen (DO) concentration was continuously monitored and the response of biomass to the feeding along with process stability was evaluated as well as the evolution of the feast phase length of SBR\#131 cycles/run assessed. About 3-4 SRT ( $20 \mathrm{~d}$ ) were required to allow the biomass to reach stability to the regime feeding and a feast/famine cycle length ratio below $0.3 \mathrm{~h} \mathrm{~h}^{-1}$ (Figure SI). The biomass behavior showed a certain stability as indicated by the low feast/cycle time ratio during the whole SBR run, with a maximum of $0.22 \mathrm{~h} \mathrm{~h}^{-1}$. Famine length observed in this study was in the range of 10-11 h, in agreement with previous reports (Colombo et al., 2019).

A trial performed by employing substrate from the digestates derived from OLR-III showed the lowest polymer content, i.e. $152 \pm 38 \mathrm{~g}^{\mathrm{PHA} \mathrm{kg}^{-1}} \mathrm{VSS}$, contrarily to OLR-I and ORL-II tests, i.e. $258 \pm 47$ and $253 \pm 75 \mathrm{~g}^{\mathrm{PHA} \mathrm{kg}^{-1}} \mathrm{VSS}$, respectively (Table 4). These differences could be related to different VFAs composition of feed and so to the lower propionic uptake rate relative to acetate, that might lead to different PHA formation 
as has previously been suggested (Fradinho et al., 2014). Studies in the literature reported a decrease in the PHA production when propionate was fed to aerobic MMC (Lemos et al., 2006; Fradinho et al., 2014). However, in that case acetate was fed during the enrichment/selection PHA stage, which was not the case for this study, as the digestate and the sludge fed were the same as those used for the PHA accumulation. Another possible explanation may be related to nutrient starvation that favors PHA synthesis, thus influencing carbon flux through the intermediates and so the resulting different yields and polymer composition, as was suggested in recent studies on metabolic flux analysis adopting different feeding strategies (Montano-Herrera et al., 2017). In particular, the presence of acetate was reported to be favorable over that of propionate in the catabolic activities of MMC with high PHA accumulation (Dias et al., 2008; Jiang et al., 2011). Further experiments must be carried out to evaluate the carbon storage and decarboxylation, as well the link with uptake rates of VFA used as carbon source, their metabolism and the oxidative phosphorylation efficiency for cellular growth and PHA production (Dias et al., 2008; Montano-Herrera et al., 2017). Such previously stated (Section 3.2.3), adopting different HRT led to different VFA profiles that can affect above all PHA composition (Table 2) (Figure 1). Butyric and acetic acids are responsible for the methane production so that their content decreased during $\mathrm{AD}$ with respect to starting content, contrarily to propionic acid. Therefore, shorter AD process (low HRT) tended to accumulate propionic acid, i.e. for HRT of $30 \mathrm{~d}$ and $20 \mathrm{~d}$ propionic acids represented $73 \%$ and $85 \%$ of total final VFA content, respectively (Table 2), contrarily to longest HRT (40 d) in which propionic acid was of $32 \%$. 
Different VFA composition registered led to changes in the polymer composition (Albuquerque et al., 2011). Acetic and butyric acids used as feed produced 3hydroxybutyrate (3-HB), while propionic and valeric acids promoted the formation of 3hydroxyvalerate (3-HV) (Bengtsson et al., 2010). Interestingly, the copolymers ratio (HB-co-HV) obtained in this work, reflected well the VFA carbon sources used as precursors in feed. Substrates from trials performed with OLR-I (HRT of $40 \mathrm{~d}$ ) and OLRII (HRT of $30 \mathrm{~d}$ ), showed HB/HV ratios of 59/41 and of 52/48, respectively, which differed from that obtained from trial OLR-III (HRT of 20 d) that measured 29/71 (HB /HV) (Table 4).

The PHA storage yield on the total organic acids fed reached $0.8 \mathrm{mg}$ CODPHA $\mathrm{mg}^{-1}$ CODVFA IN that was higher than PHA storage yield on total COD fed, which ranged between 0.14 and $0.35 \mathrm{mg} \mathrm{COD}_{\mathrm{PHA}} \mathrm{mg}^{-1} \mathrm{COD}$ IN , indicating that part of the COD was not used to produce PHA and probably that the VFAs fed were not totally consumed. This was especially evident in the case of OLR-III which showed the lowest values $(0.44 \pm 0.1$ mg COD PHA $\mathrm{mg}^{-1}$ COD VFA IN), which could be linked to the greater presence of propionate in the medium fed, leading to a possible inactivation of the TCA cycle, as previously mentioned (Jiang et al., 2011). When referring PHA yields to VFA and COD consumed, higher values were obtained (Table 4 ), indicating that nearly the totality ( $>90$ \%) of carbon sources consumed were converted to PHA, confirming that VFAs were the preferred substrate to be metabolized for the production of PHA, in agreement with previous reports (Colombo et al., 2019).

The maximum PHA levels were obtained at the end of each feast phase, with VFAs depletion and each feed pulse run cycle, ended before PHA degraded over the course of 
remaining part of the cycle. For all three tests, the VFA substrate was not completely consumed during the feast phases, but for each pulse fed a certain amount of residual carbon remained and tended to increase as each pulse was added. This may be caused by the too short period of time between one pulse and the next to achieve a complete carbon oxidation, although the dissolved oxygen signal showed an increase due to its lower consumption, due to the fact that a fraction of the soluble carbon supplied was not easily metabolized. Despite the incomplete consumption of the substrate, the concentration of PHA increased with a similar trend for each pulse. Figure 2 illustrates the trend of PHA, active biomass, VFA concentrations ( $\mathrm{g} \mathrm{L}^{-1}$ ) and PHA content (g PHA g $\left.{ }^{-1} \mathrm{VSS}\right)$. The curves of the three tests had similar slopes, which remained towards the accumulation test period of about $2.5 \mathrm{~h}$; this behavior indicated that there was no reduction of the accumulation capacity of PHA by bacteria that still have intracellular polymer concentrations not brought to saturation. PHA produced versus total substrate consumed, was determined at points where it was linear with time (approximately $2.5 \mathrm{~h}$ ), maximizing differences among different treatments and allowing consistent comparison between accumulation runs (Janarthanan et al., 2016).

Concerning PHA productivity derived from the three OLRs tested, the values obtained were overall in a similar range, varying among the trials between 4.4 and $13.5 \mathrm{~g} \mathrm{PHA} \mathrm{L}^{-1}$ $\mathrm{d}^{-1}$ (Table 4), which was in line with those obtained by Dionisi et al., (2006) where similar yields $\left(0.3 \mathrm{~g}\right.$ PHA L $\left.{ }^{-1} \mathrm{~d}^{-1}\right)$ were reported. In agreement with these results, Colombo et al., (2017) also observed similar productivities (4.4 -7 g PHA L-1 $\left.\mathrm{d}^{-1}\right)$, in a study on organic acid-rich percolate from OFMSW. 
In summary, the results obtained in this study reported a total amount of PHA referred to total solid of OFMSW (OFMSW ${ }_{\text {TS }}$ ) of $199 \pm 36 \mathrm{~g}^{\text {PHA kg}}{ }^{-1} \mathrm{OFMSW}_{\mathrm{TS}}, 193 \pm 8 \mathrm{~g}^{\mathrm{PHA} \mathrm{kg}}{ }^{-}$

${ }^{1}$ OFMSW $_{\text {TS }}$ and $117 \pm 29 \mathrm{~g}$ PHA kg ${ }^{-1}$ OFMSW $_{\text {TS, }}$, for OLR-I, OLR-II and OLR-III, respectively (Table 4). These results suggest that approximately 5-8.5 $\mathrm{kg}$ of OFMSW were required to produce $1 \mathrm{~kg}$ of PHAs, while about $30-55 \mathrm{~kg}$ of OFMSW $\mathrm{FM}_{\text {were }}$ required to produce $1 \mathrm{~kg}$ of PHAs.

Interestingly, the material balance was used to additionally explain the carbon conversion yields during the two stages process and its flow by the OFMSW source.

In particular, a comparative material balance and process yields taking in consideration the amount carbon in the different streams along the anaerobic digestion at different OLR (i.e. HRT) tested and PHA accumulation, is presented in Figure 4. Considering the absolute values in terms of mass balance, the carbon mass efficiencies whereby $1 \mathrm{~kg}$ TS of OFMSW yielded up to $37-42 \% \mathrm{C}$ as $\mathrm{CH}_{4}$, and $17-28 \% \mathrm{C}$ as PHAs, while the carbon as $\mathrm{CO}_{2}$ and digestate represented about $20 \%$ and $9-22 \%$, respectively.

\subsection{Energy output of OFMSW from biomethane and PHA production}

In order to define whether integrating $\mathrm{AD}$ with PHAs accumulation benefits the energy balance of the simple proposed biorefinery, gross and net energy balances were carried out for the three different treatments studied (i.e. OLR-I-II-III).

The energy content of the OFMSW was directly measured by combustion and the Low Heating Value (LHV) resulting was of $21.85 \mathrm{MJ} \mathrm{kg}^{-1} \mathrm{TS}$, which fell into the range typically reported for organic biomass materials (Yang et al., 2018). For the calculations of the gross energy balance, the LHV of both bio-methane and PHAs, i.e. $31.6 \mathrm{MJ} \mathrm{m}^{-3}$ 
and $22 \mathrm{MJ} \mathrm{kg}^{-1} \mathrm{TS}$ (IEA Bioeenrgy, 2006; Mohanty, et al., 2005), were considered. Additionally, the energy requirements to produce both methane and PHA have been considered in getting the net energy balance. In particular, the energy required for producing methane has been considered equal to $10 \%$ of the total energy produced by methane, as inferred from the full-scale plant and confirmed by the literature (Naegele et al., 2012). Energy needed to produce PHA has been estimated, on average, from different literature data, and gave a result of $70 \pm 26 \mathrm{MJ} \mathrm{kg}^{-1}$ of polymer produced starting from glucose from corn (Gerngross, 1999), soybean oil (Akiyama et al., 2003) or sucrose from sugarcane (Nonato et al., 2001). To produce PHA industrially, steam is considered one of the main causes of energy consumption as it is required at the rate of $40 \mathrm{~kg} \mathrm{steam} \mathrm{kg}^{-1}$ polymer (1 kg of steam required 2.5 MJ) (Gerngross, 1999; Nonato et al., 2001), and it represents about $40 \%$ of the total energy consumption needed to produce PHAs. Since in our experimental biorefinery, using MMC and VFAs as feed in producing PHA did not require the use of steam, this energy consumption need not be considered, so that the data used to obtain the energy balance was of $42 \mathrm{MJ} \mathrm{kg}^{-1}$ polymer produced. Results obtained indicated that the gross energetic output from AD process (methane) referred to $1 \mathrm{~kg}$ of OFMSW (TS basis), was, as an average of the three scenarios studied, of $11 \pm 0.7 \mathrm{MJ} \mathrm{kg} \mathrm{TS}^{-1}$; this means that about $51 \pm 3.2 \%$ of OFMSW energy was recovered as methane (Figure 3). Taking into consideration energy consumption producing biomethane, i.e. $10 \%$ of the total energy output, the net energetic output from bio-methane represented, as average for the three scenarios, $46 \pm 3 \%$ of the OFMSW total energy content. 
PHA production allowed additional energy to be recovered. Doing so taking into consideration LHV of PHA and energy required for producing PHA, gross and net energy balances for the simple biorefinery proposed have been calculated.

These results assessed an increment of energy release from $1 \mathrm{~kg}$ of OFMSW by integrating AD with PHAs production of 30\% (as average) (Figure 3). In particular, the net energy output for the three different treatments $\left(\mathrm{CH}_{4}+\mathrm{PHA}\right)$ were of $13.5 \pm 0.3 \mathrm{MJ}$

$\mathrm{kg} \mathrm{TS}^{-1}, 15.9 \pm 0.1 \mathrm{MJ} \mathrm{kg} \mathrm{TS}^{-1}$ and $12.6 \pm 0.2 \mathrm{MJ} \mathrm{kg} \mathrm{TS}^{-1}$, representing the $62 \%, 73 \%$ and $58 \%$ (Figure 3) of the energy input for OLR-I, OLR-II and OLR-III scenarios, respectively.

The shortest HRT 20 (OLR-III), even though it led to higher daily biogas release, required a lower energy increment from PHA production that was of the order of $20 \%$ of the total energy release. Nevertheless, the quality of the polymer composition (i.e. $\Delta \mathrm{HB} / \Delta \mathrm{HV}$ ), which was previously discussed, should be also taken into account in the further research efforts into increasing quantity without compromising quality of the product as well on economic feasibility.

Nonetheless economic aspects regarding PHA production should also be considered further. PHA are currently sold at price of $3.4 € \mathrm{~kg}^{-1}$ (Villegas et al., 2018) that allows greatly increasing total income from the sole production of methane from organic waste that is not sustainable from an economic point of view unless in presence of government benefits (Negri et al., 2020).

\section{Conclusion}


The simple biorefinery proposed has been proven to be effective in producing both biogas and PHA thanks to the VFAs contained in the digestate. OLR modification affected total VFAs produced, affecting total PHA production. OLR-III (HRT of $20 \mathrm{~d}$ ) although it resulted in the lowest PHA production, showed the best copolymer composition (HB/HV of 29/71) suggesting that by modifying AD parameters, both quantity and quality of PHA were affected. The integration of biomethane with PHA production allowed increasing the total net energy recovery from the OFMSW in comparison with the sole $\mathrm{AD}$ scenario of $30 \%$, while diversifying $\mathrm{AD}$ products.

\section{Acknowledgements}

This work was supported by Gruppo Ricicla labs., University of Milan (UNIMI), Italy, project N. 14135 RV_PRO_RIC16FADAN02_M.

The authors would like to thank Vincenzo D'Ardes with the energy density analysis, Pietro Squillace for HPLC analysis, Dr. Simon Kizito for the help in setting up AD and with the preliminary analysis of the feedstock. Authors are grateful to Cap Holding (Peschiera Borromeo plant, Italy) who provided the sewage sludge necessary for carrying out MMC isolation for PHA production and to Lucra 96 S.r.l AD Plant for OFMSW delivery and full scale plant data.

\section{Appendix A. Supplementary data}

Supplementary data associated with this article and relative to: feast- to famine ratio (F/F) during the PHA-producing bacteria selection process with the OFMSW and trace 
elements of OFMSW digestates generated from the AD processes can be found in the online version, at: 


\section{References}

1. Agyeman, F.O., Tao, W., 2014. Anaerobic co-digestion of food waste and dairy manure: Effects of food waste particle size and organic loading rate. J. Environ. Manage. 133, 268-274. https://doi.org/10.1016/j.jenvman.2013.12.016

2. Akiyama, M., Tsuge, T., Doi, Y., 2003. Environmental life cycle comparison of polyhydroxyalkanoates produced from renewable carbon resources by bacterial fermentation. Polym. Degrad. Stab. 80, 183-194. https://doi.org/10.1016/S0141$3910(02) 00400-7$

3. APHA Standard Methods for the examination of water and waste water ., 1998. . American Public Health Association.

4. Arthurson, V., 2009. Closing the global energy and nutrient cycles through application of biogas residue to agricultural land - potential benefits and drawbacks. Energies 2, 226-242. https://doi.org/10.3390/en20200226

5. Bengtsson, S., Pisco, A.R., Johansson, P., Lemos, P.C., Reis, M.A.M., 2010. Molecular weight and thermal properties of polyhydroxyalkanoates produced from fermented sugar molasses by open mixed cultures. J. Biotechnol. 147, 172179. https://doi.org/10.1016/j.jbiotec.2010.03.022

6. Campuzano, R., González-Martínez, S., 2016. Characteristics of the organic fraction of municipal solid waste and methane production: A review. Waste Manag. 54, 3-12. https://doi.org/10.1016/j.wasman.2016.05.016

7. Canul Bacab, F., España Gamboa, E., Ruiz Espinoza, J.E., Leal-Bautista, R.M., Tapia Tussell, R., Domínguez Maldonado, J., Canto Canché, B., Alzate-Gaviria, 
L., 2020. Two Phase Anaerobic Digestion System of Municipal Solid Waste by Utilizing Microaeration and Granular Activated Carbon. Energies 13, (933), 1-19. https://doi.org/10.3390/en13040933

8. Cavinato, C., Frison, N., Herrero, N., Gottardo, M., Da, C., Strazzera, G., Cherubin, A., Fatone, F., Pavan, P., Bolzonella, D., 2017. Volatile fatty acids production from organic waste for biorefinery platforms. In 5th International Conference on Sustainable Solid Waste Management; Athens, Greece.

9. Chen, Y., Cheng, J.J., Creamer, K.S., 2008. Inhibition of anaerobic digestion process: A review. Bioresour. Technol. 99, 4044-4064. https://doi.org/10.1016/j.biortech.2007.01.057

10. Colombo, B., Favini, F., Scaglia, B., Sciarria, T.P., D’Imporzano, G., Pognani, M., Alekseeva, A., Eisele, G., Cosentino, C., Adani, F., 2017. Enhanced polyhydroxyalkanoate (PHA) production from the organic fraction of municipal solid waste by using mixed microbial culture. Biotechnol. Biofuels 10, (201), 115. https://doi.org/10.1186/s13068-017-0888-8

11. Colombo, B., Villegas Calvo, M., Pepè Sciarria, T., Scaglia, B., Savio Kizito, S., D’Imporzano, G., Adani, F., 2019. Biohydrogen and polyhydroxyalkanoates (PHA) as products of a two-steps bioprocess from deproteinized dairy wastes. Waste Manag. 95, 22-31. https://doi.org/10.1016/j.wasman.2019.05.052

12. Dang, Y., Holmes, D.E., Zhao, Z., Woodard, T.L., Zhang, Y., Sun, D., Wang, L.Y., Nevin, K.P., Lovley, D.R., 2016. Enhancing anaerobic digestion of complex organic waste with carbon-based conductive materials. Bioresour. Technol. 220, 516-522. https://doi.org/10.1016/j.biortech.2016.08.114 
13. Di Maria, F., Sisani, F., Norouzi, O., Mersky, R.L., 2019. The effectiveness of anaerobic digestion of bio-waste in replacing primary energies: An EU28 case study. Renew. Sustain. Energy Rev. 108, 347-354. https://doi.org/10.1016/j.rser.2019.03.047

14. Dias, J.M., Oehmen, A., Serafim, L.S., Lemos, P.C., Reis, M.A., Oliveira, R., 2008. Metabolic modelling of polyhydroxyalkanoate copolymers production by mixed microbial cultures. BMC Syst. Biol. 2, (59) 1-21 https://doi.org/10.1186/1752-0509-2-59

15. Dionisi, D., Majone, M., Vallini, G., Di Gregorio, S., Beccari, M., 2006. Effect of the applied organic load rate on biodegradable polymer production by mixed microbial cultures in a sequencing batch reactor. Biotechnol. Bioeng. 93, 76-88. https://doi.org/10.1002/bit.20683

16. Duque, A.F., Oliveira, C.S.S., Carmo, I.T.D., Gouveia, A.R., Pardelha, F., Ramos, A.M., Reis, M.A.M., 2014. Response of a three-stage process for PHA production by mixed microbial cultures to feedstock shift: impact on polymer composition. New Biotechnol. 31, 276-288. https://doi.org/10.1016/j.nbt.2013.10.010

17. Eriksson, M., Strid, I., Hansson, P.-A., 2015. Carbon footprint of food waste management options in the waste hierarchy - a Swedish case study. J. Clean. Prod. 93, 115-125. https://doi.org/10.1016/J.JCLEPRO.2015.01.026

18. Fradinho, J.C., Oehmen, A., Reis, M.A.M., 2014. Photosynthetic mixed culture polyhydroxyalkanoate (PHA) production from individual and mixed volatile fatty acids (VFAs): Substrate preferences and co-substrate uptake. J. Biotechnol. 185, 19-27. https://doi.org/10.1016/j.jbiotec.2014.05.035 
19. Franke-Whittle, I.H., Walter, A., Ebner, C., Insam, H., 2014. Investigation into the effect of high concentrations of volatile fatty acids in anaerobic digestion on methanogenic communities. Waste Manag. 34, 2080-2089. https://doi.org/10.1016/j.wasman.2014.07.020

20. Gerngross, T.U., 1999. Can biotechnology move us toward a sustainable society? Nat. Biotechnol. 17, 541-544. https://doi.org/10.1038/9843

21. Girotto, F., Alibardi, L., Cossu, R., 2015. Food waste generation and industrial uses: A review. Waste Manag. 45, 32-41 https://doi.org/10.1016/j.wasman.2015.06.008

22. Hoornweg, D., Bhada-Tata, P., 2012. What a Waste : A Global Review of Solid Waste Management.Urban development series;knowledge papers no. 15. World Bank, Washington, DC. ( ) World Bank.

23. Janarthanan, O.M., Laycock, B., Montano-Herrera, L., Lu, Y., Arcos-Hernandez, M.V., Werker, A., Pratt, S., 2016. Fluxes in PHA-storing microbial communities during enrichment and biopolymer accumulation processes. New Biotechnol. 33, 61-72. https://doi.org/10.1016/j.nbt.2015.07.007

24. Jankowska, E., Chwiałkowska, J., Stodolny, M., Oleskowicz-Popiel, P., 2015. Effect of $\mathrm{pH}$ and retention time on volatile fatty acids production during mixed culture fermentation. Bioresour. Technol. 190, 274-280. https://doi.org/10.1016/j.biortech.2015.04.096

25. Jiang, J., Zhang, Y., Li, K., Wang, Q., Gong, C., Li, M., 2013. Volatile fatty acids production from food waste: Effects of $\mathrm{pH}$, temperature, and organic loading rate. Bioresour. Technol. 143, 525-530. https://doi.org/10.1016/j.biortech.2013.06.025 
26. Jiang, Y., Dennehy, C., Lawlor, P.G., Hu, Z., McCabe, M., Cormican, P., Zhan, X., Gardiner, G.E., 2018. Inhibition of volatile fatty acids on methane production kinetics during dry co-digestion of food waste and pig manure. Waste Manag. 79, 302-311. https://doi.org/10.1016/j.wasman.2018.07.049

27. Jiang, Y., Hebly, M., Kleerebezem, R., Muyzer, G., van Loosdrecht, M.C.M., 2011. Metabolic modeling of mixed substrate uptake for polyhydroxyalkanoate (PHA) production. Water Res. 45, 1309-1321. https://doi.org/10.1016/j.watres.2010.10.009

28. Khan, M.A., Ngo, H.H., Guo, W.S., Liu, Y., Nghiem, L.D., Hai, F.I., Deng, L.J., Wang, J., Wu, Y., 2016. Optimization of process parameters for production of volatile fatty acid, biohydrogen and methane from anaerobic digestion. Bioresour. Technol. 219, 738-748. https://doi.org/10.1016/j.biortech.2016.08.073

29. Lemos, P.C., Serafim, L.S., Reis, M.A.M., 2006. Synthesis of polyhydroxyalkanoates from different short-chain fatty acids by mixed cultures submitted to aerobic dynamic feeding. J. Biotechnol. 122, 226-238. https://doi.org/10.1016/j.jbiotec.2005.09.006

30. Lim, S.-J., Kim, B.J., Jeong, C.-M., Choi, J., Ahn, Y.H., Chang, H.N., 2008. Anaerobic organic acid production of food waste in once-a-day feeding and drawing-off bioreactor. Bioresour. Technol. 99, 7866-7874. https://doi.org/10.1016/j.biortech.2007.06.028

31. Mohanty, A. K., Misra, M., Drzal, L., 2005. Natural Fibers, Biopolymers, and Biocomposites. Eds.; CRC Press:, Boca Raton, FL. 
32. Molino, A., Nanna, F., Ding, Y., Bikson, B., Braccio, G., 2013. Biomethane production by anaerobic digestion of organic waste. Fuel 103, 1003-1009. https://doi.org/10.1016/J.FUEL.2012.07.070

33. Montano-Herrera, L., Laycock, B., Werker, A., Pratt, S., 2017. The Evolution of Polymer Composition during PHA Accumulation: The Significance of Reducing Equivalents. Bioengineering 4, (20) 1-17. https://doi.org/10.3390/bioengineering 4010020

34. Moretto, G., Russo, I., Bolzonella, D., Pavan, P., Majone, M., Valentino, F., 2020. An urban biorefinery for food waste and biological sludge conversion into polyhydroxyalkanoates and biogas. Water Res. 170, 1-12. https://doi.org/10.1016/j.watres.2019.115371

35. Naegele, H.-J., Lemmer, A., Oechsner, H., Jungbluth, T., 2012. Electric Energy Consumption of the Full Scale Research Biogas Plant "Unterer Lindenhof": Results of Longterm and Full Detail Measurements. Energies 5, 5198-5214. https://doi.org/10.3390/en5125198

36. Negri C., Ricci. M., Zilio. M., D’Imporzano. G., Qiao. W., Dong. R., Adani F., 2020. Anaerobic digestion of food waste for bio-energy production in China and Southeast Asia: A review. Renewable and Sustainable Energy Reviews 133, 110138, https://doi.org/10.1016/j.rser.2020.110138

37. Nonato, R., Mantelatto, P., Rossel, C., 2001. Integrated production of biodegradable plastic, sugar and ethanol. Appl. Microbiol. Biotechnol. 57, 1-5. https://doi.org/10.1007/s002530100732 
38. Oliveira, C.S.S., Silva, C.E., Carvalho, G., Reis, M.A., 2017. Strategies for efficiently selecting PHA producing mixed microbial cultures using complex feedstocks: Feast and famine regime and uncoupled carbon and nitrogen availabilities. New Biotechnol. 37, 69-79. https://doi.org/10.1016/j.nbt.2016.10.008

39. Persson M, Jonsson O, Wellinger A, 2006. International Energy Agency (IEA) Bioenergy. Biogas upgrading to vehicle fuel standards and grid injection. IEA Bioenergy Task 37- Energy from Biogas, IEA Bioenergy.

40. Pittmann, T., Steinmetz, H., 2013. Influence of operating conditions for volatile fatty acids enrichment as a first step for polyhydroxyalkanoate production on a municipal waste water treatment plant. Bioresour. Technol. 148, 270-276. https://doi.org/10.1016/j.biortech.2013.08.148

41. Rajput, A.A., Sheikh, Z., 2019. Effect of inoculum type and organic loading on biogas production of sunflower meal and wheat straw. Sustain. Environ. Res. 29, (4) 1-10. https://doi.org/10.1186/s42834-019-0003-x

42. Reddy, C.S.K., Ghai, R., Rashmi, Kalia, V.C., 2003. Polyhydroxyalkanoates: an overview. Bioresour. Technol. 87, 137-146. https://doi.org/10.1016/S0960$8524(02) 00212-2$

43. Sarker, S., Lamb, J.J., Hjelme, D.R., Lien, K.M., 2019. A Review of the Role of Critical Parameters in the Design and Operation of Biogas Production Plants. Appl. Sci. 9, (1915) 1-38. https://doi.org/10.3390/app9091915 
44. Scarlat, N., Fahl, F., Dallemand, J.F., 2019. Status and Opportunities for Energy Recovery from Municipal Solid Waste in Europe. Waste Biomass Valorization 10, 2425-2444. https://doi.org/10.1007/s12649-018-0297-7

45. Slezak, R., Grzelak, J., Krzystek, L., Ledakowicz, S., 2017. The effect of initial organic load of the kitchen waste on the production of VFA and H 2 in dark fermentation. Waste Manag. 68, 610-617. https://doi.org/10.1016/j.wasman.2017.06.024

46. Valentino, F., Beccari, M., Fraraccio, S., Zanaroli, G., Majone, M., 2014. Feed frequency in a Sequencing Batch Reactor strongly affects the production of polyhydroxyalkanoates (PHAs) from volatile fatty acids. New Biotechnol. 31, 264-275. https://doi.org/10.1016/j.nbt.2013.10.006

47. Valentino, F., Gottardo, M., Micolucci, F., Pavan, P., Bolzonella, D., Rossetti, S., Majone, M., 2018. Organic Fraction of Municipal Solid Waste Recovery by Conversion into Added-Value Polyhydroxyalkanoates and Biogas. ACS Sustain. Chem. Eng. 6, 16375-16385. https://doi.org/10.1021/acssuschemeng.8b03454

48. Valentino, F., Moretto, G., Lorini, L., Bolzonella, D., Pavan, P., Majone, M., 2019. Pilot-Scale Polyhydroxyalkanoate Production from Combined Treatment of Organic Fraction of Municipal Solid Waste and Sewage Sludge. Ind. Eng. Chem. Res. 58, 12149-12158. https://doi.org/10.1021/acs.iecr.9b01831 49. Villegas Calvo, M., Colombo, B., Corno, L., Eisele, G., Cosentino, C., Papa, G., Scaglia, B., Pilu, R., Simmons, B., Adani, F., 2018. Bioconversion of Giant Cane for Integrated Production of Biohydrogen, Carboxylic Acids, and Polyhydroxyalkanoates (PHAs) in a Multistage Biorefinery Approach. ACS 
Sustain. Chem. Eng. 6, 15361-15373.

https://doi.org/10.1021/acssuschemeng.8b03794

50. Yang, Y., Heaven, S., Venetsaneas, N., Banks, C.J., Bridgwater, A.V., 2018.

Slow pyrolysis of organic fraction of municipal solid waste (OFMSW):

Characterisation of products and screening of the aqueous liquid product for anaerobic digestion. Appl. Energy 213, 158-168.

https://doi.org/10.1016/j.apenergy.2018.01.018 
Table 1. Anaerobic process parameters

\begin{tabular}{lccc}
\hline \multirow{2}{*}{ Operation Parameters } & \multicolumn{3}{c}{ Hydraulic retention time (HRT) } \\
& $\mathbf{4 0}$ & $\mathbf{3 0}$ & $\mathbf{2 0}$ \\
\hline Reactor volume $(\mathrm{L})$ & 1.5 & 1.5 & 1.5 \\
Temperature $\left({ }^{\circ} \mathrm{C}\right)$ & 55 & 55 & 55 \\
HRT $(\mathrm{d})$ & 43 & 30 & 20 \\
OFMSW daily feed $(\mathrm{g} \mathrm{FM})$ & 35 & 50 & 74 \\
TS feed $(\mathrm{g})$ & 5.53 & 7.9 & 11.63 \\
VS input $(\mathrm{g})$ & 4.26 & 6.08 & 8.96 \\
Organic loading rate $\left(\mathrm{kg} \mathrm{VS} \mathrm{m} \mathrm{d} \mathrm{d}^{-1}\right)$ & 3 & 4 & 6 \\
CODt loading daily feed $\left(\mathrm{g} \mathrm{d}^{-1}\right)$ & 3.4 & 4.8 & 7.1 \\
CODs loading daily feed $\left(\mathrm{g} \mathrm{d}^{-1}\right)$ & 2.1 & 3 & 4.5 \\
\hline
\end{tabular}


Table 2. Characteristics of OFMSW and inoculum used to feed the phased digestion systems and the digestates generated from the $\mathrm{AD}$ processes.

\begin{tabular}{|c|c|c|c|c|c|}
\hline \multirow[t]{2}{*}{ Parameter } & \multirow[t]{2}{*}{ Inoculum } & \multirow[t]{2}{*}{ OFMSW } & \multicolumn{3}{|c|}{$\begin{array}{c}\text { Digestate } \\
\text { Hydraulic retention time (HRT) }\end{array}$} \\
\hline & & & $40 d$ & $30 d$ & 20d \\
\hline Total Solids TS $\left(\mathrm{g} \mathrm{kg}^{-1} \mathrm{ww}\right)$ & $20 \pm 1$ & $158 \pm 25$ & $31 \pm 8$ & $52 \pm 0.2$ & $65 \pm 4.5$ \\
\hline Volatile Solids VS $\left(\mathrm{g} \mathrm{kg}^{-1} \mathrm{ww}\right)$ & $11.3 \pm 0.7$ & $122 \pm 19$ & $20 \pm 2$ & $37 \pm 0.0$ & $47 \pm 0.6$ \\
\hline $\mathrm{VS} / \mathrm{TS}$ & $0.56 \pm 0.04$ & $0.77 \pm 0.16$ & $0.64 \pm 0.13$ & $0.7 \pm 0.0$ & $0.7 \pm 0.0$ \\
\hline $\operatorname{CODt}\left(\mathrm{g} \mathrm{L}^{-1}\right)$ & $8.9 \pm 0.2$ & $96.3 \pm 0.9$ & $28 \pm 5$ & $49 \pm 8$ & $55 \pm 10$ \\
\hline CODs $\left(\mathrm{g} \mathrm{L}^{-1}\right)$ & $3.6 \pm 0.1$ & $60.5 \pm 1.2$ & $9.8 \pm 0.3$ & $17.5 \pm 0.7$ & $19.5 \pm 1.1$ \\
\hline $\mathrm{N}$ tot $\left(\mathrm{g} \mathrm{L}^{-1}\right)$ & $5 \pm 0$ & $4.2 \pm 0.1$ & $1.5 \pm 0.0$ & $2.9 \pm 0.0$ & $3.8 \pm 0.0$ \\
\hline $\mathrm{pH}$ & $8.1 \pm 0.2$ & $6 \pm 0.1$ & $8 \pm 0$ & $8 \pm 0$ & $8.2 \pm 0.0$ \\
\hline Ash $(\%)$ & $22.5 \pm 3.1$ & $18 \pm 0$ & $35 \pm 0$ & $29 \pm 0$ & $28 \pm 0.6$ \\
\hline Alk. tot $\left(\mathrm{mg} \mathrm{CaCO}_{3} \mathrm{~L}^{-1}\right)$ & $14,000 \pm 728$ & $19,263 \pm 640$ & $\begin{array}{c}11,195 \pm 1,82 \\
1\end{array}$ & $14,202 \pm 1,206$ & $15,882 \pm 397$ \\
\hline VFA/Alk. & $0.1 \pm 0.0$ & $1.17 \pm 0.01$ & $0.18 \pm 0.1$ & $0.49 \pm 0.11$ & $0.52 \pm 0.09$ \\
\hline $\mathrm{NH}_{4}-\mathrm{N}\left(\mathrm{g} \mathrm{kg}^{-1} \mathrm{TS}\right)$ & $200 \pm 5$ & $10.6 \pm 0.4$ & $71 \pm 16$ & $64 \pm 5$ & $102 \pm 3$ \\
\hline $\mathrm{NH}_{4}-\mathrm{N}\left(\mathrm{mg} \mathrm{L}^{-1}\right)$ & $4,000 \pm 56$ & $1,671 \pm 20$ & $2,200 \pm 339$ & $3,300 \pm 255$ & $6,650 \pm 146$ \\
\hline \multicolumn{6}{|l|}{ Volatile fatty acid } \\
\hline VFA $\mathrm{mg} \mathrm{L}^{-1}$ & $1,335 \pm 8$ & $23,534 \pm 1,778$ & $3,158 \pm 26$ & $5,261 \pm 199$ & $6,871 \pm 71$ \\
\hline VFA $\left(\mathrm{g} \mathrm{kg}^{-1} \mathrm{TS}\right)$ & $67 \pm 3$ & $149 \pm 11$ & $103 \pm 9$ & $102 \pm 4$ & $106 \pm 2$ \\
\hline \multicolumn{6}{|l|}{ Organic acid speciation } \\
\hline Acetic $\mathrm{mg} \mathrm{L}^{-1}(\%)$ & n.d & $\begin{array}{l}7,965 \pm 593 \\
(34)\end{array}$ & $\begin{array}{l}2,148 \pm 22 \\
\quad(68)\end{array}$ & $\begin{array}{l}1,419 \pm 60 \\
(27)\end{array}$ & $\begin{array}{l}1,051 \pm 9.2 \\
(15)\end{array}$ \\
\hline Propionic $\mathrm{mg} \mathrm{L}^{-1}(\%)$ & n.d & $\begin{array}{l}5,781 \pm 262 \\
\quad(25)\end{array}$ & $\begin{array}{l}1,010 \pm 59 \\
(32)\end{array}$ & $\begin{array}{l}3,842 \pm 190 \\
\quad(73)\end{array}$ & $\begin{array}{l}5,820 \pm 70 \\
(84)\end{array}$ \\
\hline Butyric mg L ${ }^{-1}(\%)$ & n.d & $\begin{array}{c}8,066 \pm 1552 \\
(34)\end{array}$ & 0 & 0 & 0 \\
\hline Valeric $\mathrm{mg} \mathrm{L}^{-1}(\%)$ & n.d & $\begin{array}{c}1,837 \pm 79 \\
(8)\end{array}$ & 0 & 0 & 0 \\
\hline
\end{tabular}


Table 3. Biogas/biomethane and organic acids production for the different organic loading rates (OLR) tested during the anaerobic digestion of OFMSW.

\begin{tabular}{|c|c|c|c|}
\hline Parameter & $\begin{array}{c}\text { OLR I } \\
(\text { HRT } 40 d) \\
\left(3 \mathrm{~g} \mathrm{VS} \mathrm{L}_{\left.\text {react }^{-1} \mathrm{~d}^{-1}\right)}\right.\end{array}$ & $\begin{array}{c}\text { OLR II } \\
(\text { HRT 30d }) \\
\left(4 \mathrm{~g} \mathrm{VS} \mathrm{L}_{\left.\text {react }^{-1} \mathrm{~d}^{-1}\right)}\right.\end{array}$ & $\begin{array}{c}\text { OLR III } \\
(\text { HRT 20d }) \\
\left(6 \mathrm{~g} \mathrm{VS} \mathrm{L}_{\text {react }}^{-1} \mathrm{~d}^{-1}\right)\end{array}$ \\
\hline \multicolumn{4}{|l|}{ Biogas/Biomethane Yields } \\
\hline $\begin{array}{l}\text { Daily Gas Volume }\left(\mathrm{NL} \mathrm{L}_{\text {react }}{ }^{-1} \mathrm{~d}^{-1}\right) \\
\mathrm{CH}_{4} \text { content }(\%, \mathrm{v} / \mathrm{v}) \\
\text { Biogas yield }\left(\mathrm{NL} \mathrm{kg} \mathrm{VS}^{-1}\right) \\
\mathrm{CH}_{4} \text { yield }\left(\mathrm{NL} \mathrm{kg}^{-1} \mathrm{OFMSW}_{\mathrm{VS}}\right) \\
\mathrm{CH}_{4} \text { yield }\left(\mathrm{NL} \mathrm{kg}^{-1} \mathrm{OFMSW}_{\mathrm{TS}}\right)\end{array}$ & $\begin{array}{l}1.5 \pm 0.1 \mathrm{a}^{\mathrm{a}} \\
67 \pm 2 \mathrm{a} \\
522 \pm 27 \mathrm{a} \\
350 \pm 18 \mathrm{a} \\
268 \pm 14 \mathrm{a}\end{array}$ & $\begin{array}{c}2.4 \pm 0.2 \mathrm{~b} \\
66 \pm 3 \mathrm{a} \\
600 \pm 51 \mathrm{a} \\
396 \pm 34 \mathrm{a} \\
303 \pm 26 \mathrm{a}\end{array}$ & $\begin{array}{l}3.4 \pm 0.2 \mathrm{c} \\
64 \pm 3 \mathrm{a} \\
567 \pm 25 \mathrm{a} \\
363 \pm 16 \mathrm{a} \\
278 \pm 12 \mathrm{a}\end{array}$ \\
\hline \multicolumn{4}{|l|}{$V F A$} \\
\hline 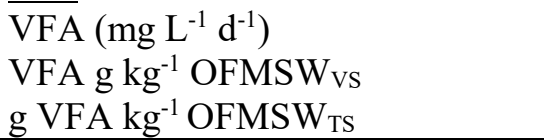 & $\begin{array}{l}79 \pm 0.6 \mathrm{a} \\
28 \pm 0.2 \mathrm{a} \\
22 \pm 4.5 \mathrm{a}\end{array}$ & $\begin{array}{c}175 \pm 5 b \\
43 \pm 1.2 b \\
33 \pm 7 b\end{array}$ & $\begin{array}{c}344 \pm 1.8 \mathrm{c} \\
57 \pm 0.6 \mathrm{c} \\
44 \pm 9 \mathrm{c}\end{array}$ \\
\hline
\end{tabular}

${ }^{a}$ Values followed by the same letter are not statistically different (ANOVA, $p<0.05$, Tukey test). 
Table 4. Characterization and performance of mixed microbial cultures during the PHA accumulation process.

\begin{tabular}{|c|c|c|c|}
\hline Parameter & $\begin{array}{c}\text { OLR I } \\
\left(3 \mathrm{gVS} \mathrm{L}^{-1} \mathbf{d}^{-1}\right)\end{array}$ & $\begin{array}{c}\text { OLR II } \\
\left(4 \mathrm{gVS} \mathrm{L}^{-1} d^{-1}\right)\end{array}$ & $\begin{array}{l}\text { OLR III } \\
\left(6 \mathrm{gVS} \mathrm{L}^{-1} d^{-1}\right)\end{array}$ \\
\hline PHA content $\left(\mathrm{g} \mathrm{PHA} \mathrm{kg}^{-1} \mathrm{VSS}\right)^{\mathrm{a}}$ & $258 \pm 47 b^{1}$ & $253 \pm 75 b$ & $152 \pm 38 \mathrm{a}$ \\
\hline Polymer composition $(\Delta \mathrm{HB} / \Delta \mathrm{HV})(\% \mathrm{w} / \mathrm{w})$ & $59 / 41 \pm 1.5 \mathrm{a}$ & $52 / 48 \pm 6.2 \mathrm{a}$ & $29 / 71 \pm 2 b$ \\
\hline Yield PHA/COD ${ }_{\text {cons }}\left(\mathrm{mg} \mathrm{COD}_{\mathrm{PHA}} \mathrm{mg}^{-1} \mathrm{COD}_{\text {cons }}\right)^{\mathrm{b}}$ & $0.90 \pm 0.2 \mathrm{a}$ & $0.87 \pm 0.1 \mathrm{a}$ & $0.94 \pm 0.4 \mathrm{a}$ \\
\hline Yield PHA/COD ${ }_{\text {IN }}\left(\mathrm{mg} \mathrm{COD}_{\mathrm{PHA}} \mathrm{mg}^{-1} \mathrm{COD}_{\mathrm{IN}}\right)^{\mathrm{c}}$ & $0.35 \pm 0.04 b$ & $0.26 \pm 0.1 b$ & $0.14 \pm 0.0 \mathrm{a}$ \\
\hline Yield PHA/COD ${ }_{\text {IN }}\left(\text { g PHA g }^{-1} \text { COD }_{\text {IN }}\right)^{d}$ & $0.20 \pm 0.02 \mathrm{a}$ & $0.15 \pm 0.1 \mathrm{a}$ & $0.08 \pm 0.0 \mathrm{a}$ \\
\hline Yield PHA/VFA $A_{\text {cons }}\left(m g \text { COD }{ }_{\mathrm{PHA}} \mathrm{mg}^{-1} \mathrm{COD}_{\mathrm{VFA}} \text { cons }\right)^{\mathrm{e}}$ & $0.98 \pm 0.02 \mathrm{a}$ & $1.50 \pm 0.6 b$ & $1.40 \pm 0.6 b$ \\
\hline Yield PHA/VFA ${ }_{\text {IN }}($ mg COD & $0.82 \pm 0.2 b$ & $0.81 \pm 0.3 b$ & $0.44 \pm 0.1 \mathrm{a}$ \\
\hline Yield PHA/VFA ${ }_{I N}\left(\mathrm{~g} \mathrm{PHA} \mathrm{g}^{-1} \mathrm{VFA}_{\mathrm{IN}}\right)^{\mathrm{g}}$ & $0.53 \pm 0.13 b$ & $0.87 \pm 0.1 \mathrm{c}$ & $0.40 \pm 0.1 \mathrm{a}$ \\
\hline$-\mathrm{q} \operatorname{COD}\left(\mathrm{mg} \operatorname{COD~g^{-1}} \operatorname{COD}_{x} \mathrm{~h}^{-1}\right)^{\mathrm{h}}$ & $243 \pm 19 \mathrm{a}$ & $479 \pm 184 b$ & $306 \pm 73 b$ \\
\hline q PHA $\left(m \text { COD }_{\text {PHA }} g^{-1} \operatorname{COD}_{x} h^{-1}\right)^{i}$ & $154 \pm 68 \mathrm{a}$ & $303 \pm 33 c$ & $198 \pm 17 b$ \\
\hline Productivity $\left(\right.$ g PHA L $\left.^{-1} \mathrm{~d}^{-1}\right)$ & $5.50-6.3$ & $4.40-8.5$ & $7-13.5$ \\
\hline $\mathrm{g}^{\mathrm{PHA} \mathrm{kg}} \mathrm{kg}^{-1} \mathrm{OFMSW}_{\mathrm{FM}}$ & $31 \pm 6 b$ & $30 \pm 1 b$ & $18 \pm 5 \mathrm{a}$ \\
\hline $\mathrm{g}$ PHA kg-1 $\mathrm{OFMSW}_{\mathrm{TS}}$ & $199 \pm 36 b$ & $193 \pm 8 b$ & $117 \pm 29 \mathrm{a}$ \\
\hline $\begin{array}{l}\text { aPHA accumulated at the end of the accumulation te } \\
\text { bPHA storage yield as COD referred to COD consur } \\
\text { 'PHA storage yield as COD referred to COD fed } \\
\text { dPHA produced referred to COD fed } \\
\text { ePHA storage yield as COD referred to VFA consun } \\
\text { 'PHA storage yield as COD referred to VFA fed } \\
\text { gPHA produced referred to VFA fed } \\
{ }^{\text {'}} \text { COD consumption rate during feast phase } \\
{ }^{\text {i }} \text { PHA specific storage rate }\end{array}$ & $\begin{array}{l}\text { est } \\
\text { Imed } \\
\text { med }\end{array}$ & & \\
\hline
\end{tabular}


Figure 1. Concentration of VFA and their composition in the OFMSW and in the digestates derived from organic loading rates (OLR) tested OLR-I, OLR-II, OLR-III.

Figure 2. Profiles of active biomass (X), VFA, PHA yields $\left(\mathrm{g} \mathrm{L}^{-1}\right)$ and content $\left(\mathrm{g} \mathrm{g}^{-1}\right.$ VSS) during the accumulation process from VFA-rich streams derived from organic loading rates (OLR) tested (a) OLR-I, (b) OLR-II, (c) OLR-III.

Figure 3. Energy balance performed for OFMSW conversion under three scenarios (OLRI-II-III). Bar charts indicate Low Heating Value (LHV), total gross energy (blue bars) and total net energy (green bars) produced as biomethane $\left(-\mathrm{CH}_{4}\right)$ and as sum of biomethane + PHA $\left(\mathrm{CH}_{4}+\mathrm{PHA}\right)$. Error bars depict standard deviation.

Figure 4 Carbon mass balances flowchart (a) and carbon yields distribution (i.e $\mathrm{CH}_{4}, \mathrm{CO}_{2}$, digestate and PHA) (b) in the different streams generated during the anaerobic digestion under three OLRs (i.e. HRT) tested and PHA accumulation. 


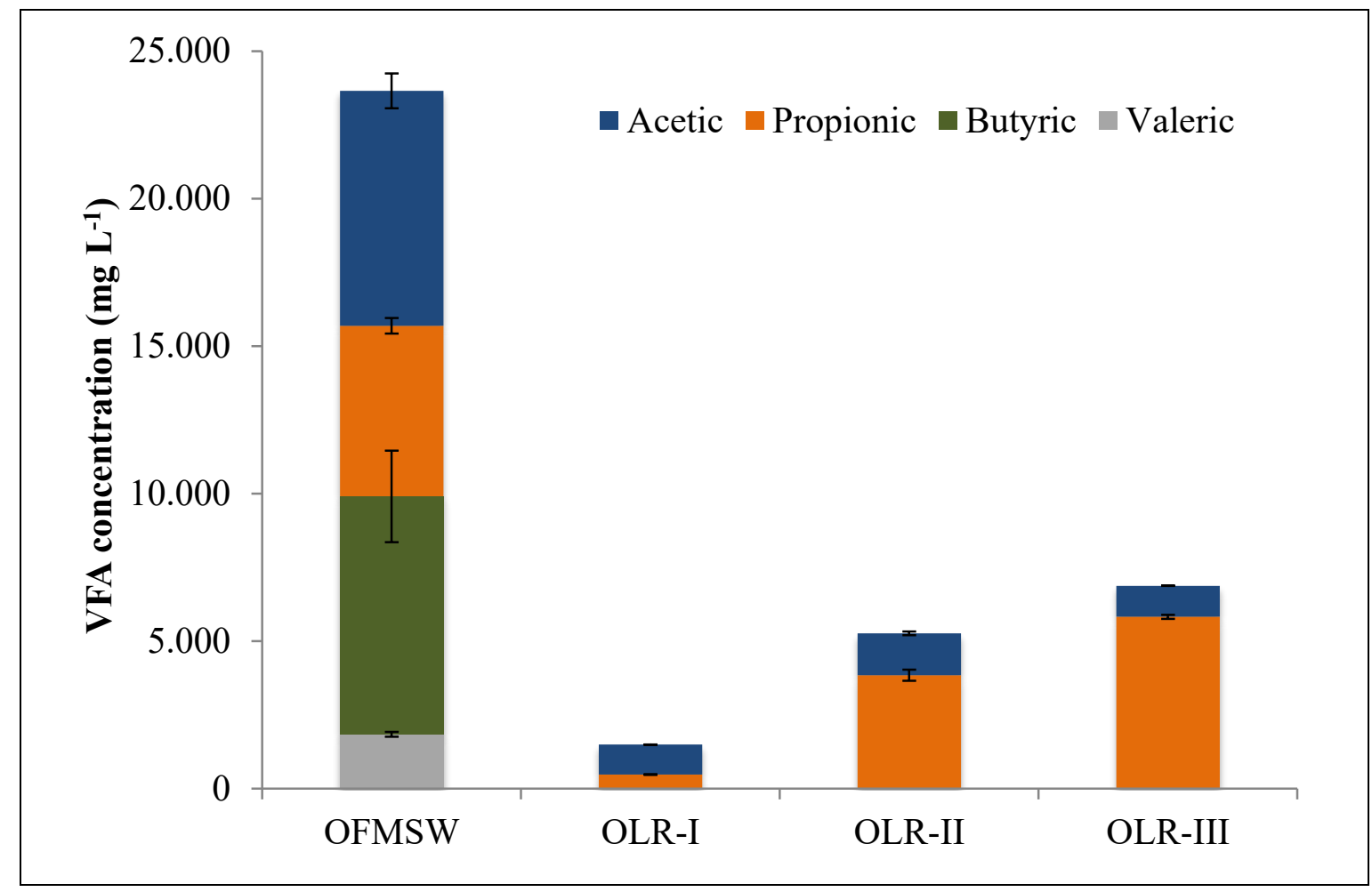




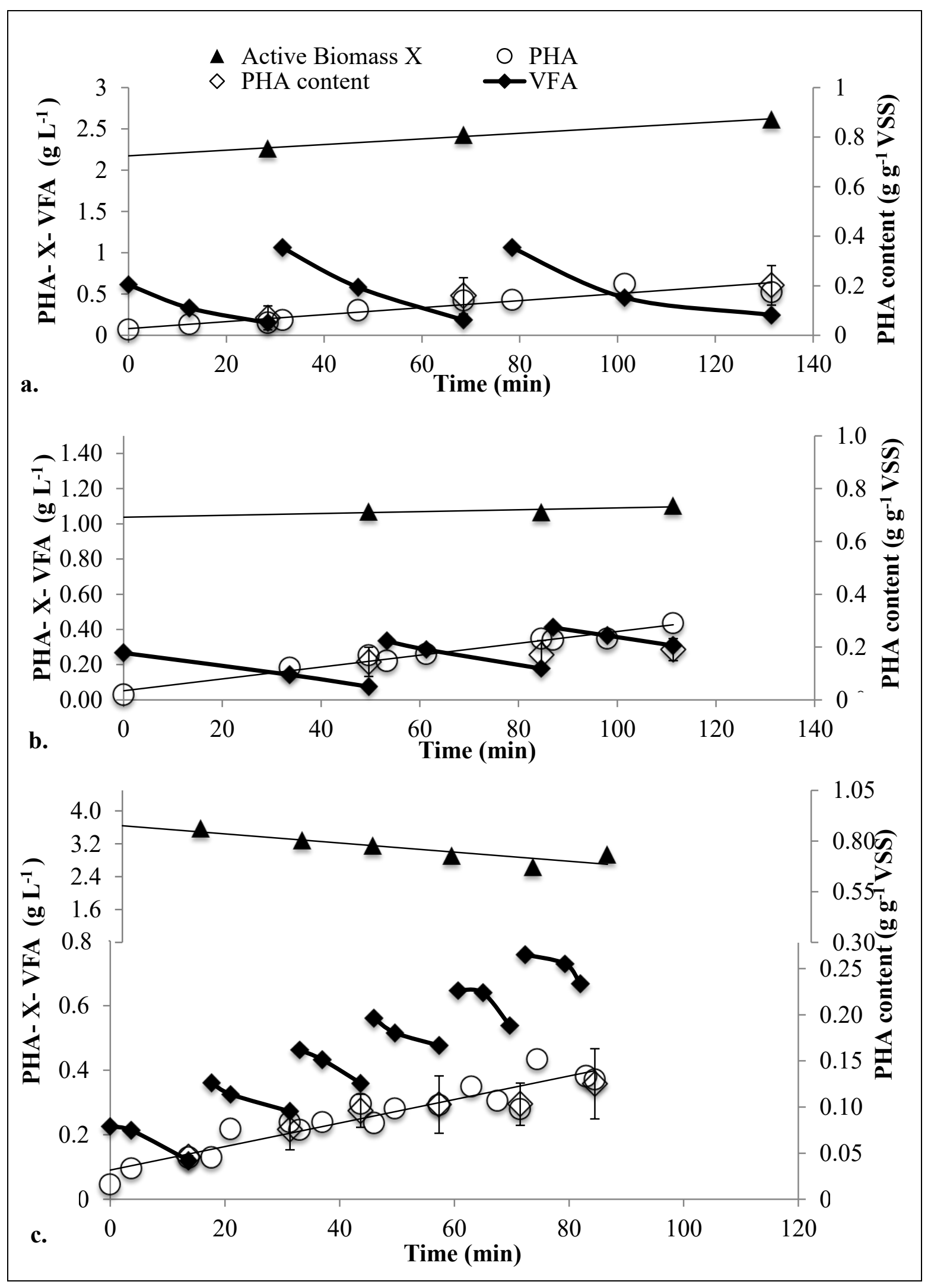




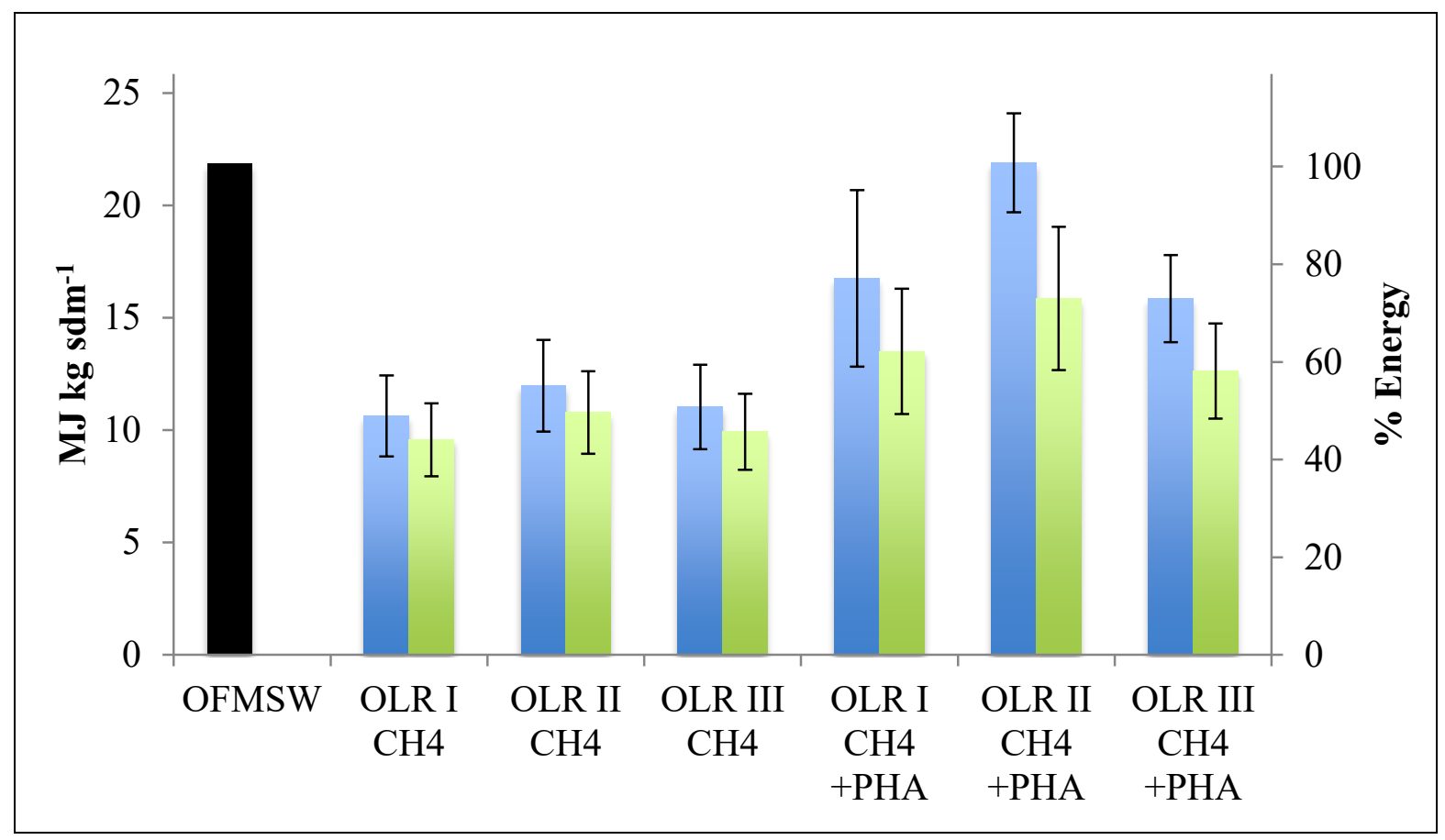




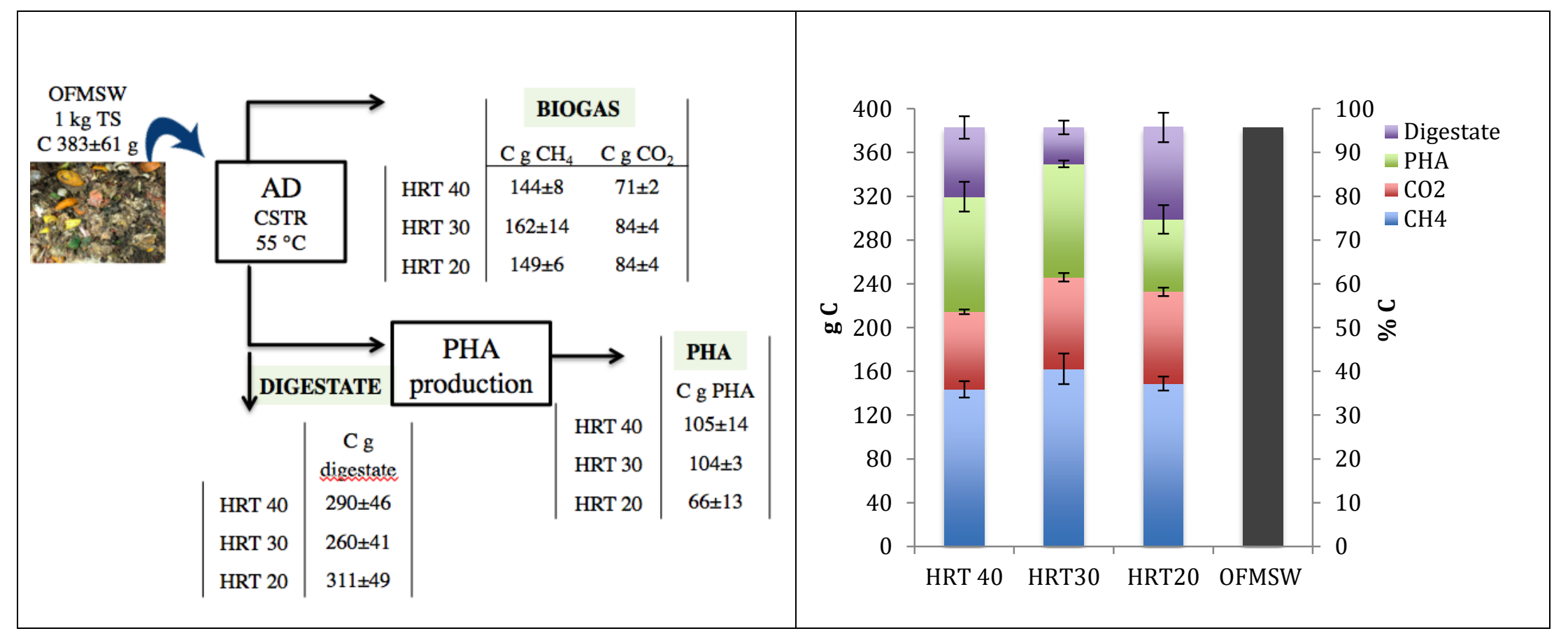

